\title{
MulawarmanLawReview
}

\section{Corporate Prosecution in Criminal Acts of Corruption: Opportunity and Challenge}

\author{
Andi Muhammad Sofyan \\ Faculty of Law, Hasanuddin University, Indonesia. \\ E-mail:ams19620501@gmail.com
}

\begin{abstract}
The corporation as an entity or legal subject whose existence contributes greatly in promoting economic growth and national development. However in reality, it is often for corporations to commit various criminal acts (corporate crime) that have a detrimental impact on the state and people. This research is normative legal research. Legal research which places the law as a normative system. The research approach uses a statutory approach and a conceptual approach. The results showed that the enactment of the Supreme Court Regulation No. 13 Year 2016 was to clarify the guidelines for the Public Prosecutor in prosecuting corporate defendants in corruption criminal acts. The application of sanctions against corporations as perpetrators of corruption is carried out as an effort to recover the losses of the State and the restoration of the state's economy is an appropriate step considering the essence of criminal punishment in eradicating criminal acts of corruption aimed at recovering state losses or the state's economy.
\end{abstract}

Keywords: Corporation; Corruption; Criminal act.

\begin{abstract}
ABSTRAK
Korporasi sebagai suatu entitas atau subjek hukum yang keberadaannya memberikan kontribusi yang besar dalam meningkatkan pertumbuhan ekonomi dan pembangunan nasional. Namun dalam kenyataannya, tak jarang korporasi melakukan pelbagai tindak pidana (corporate crime) yang membawa dampak kerugian terhadap negara dan masyarakat. Penelitian ini adalah penelitian hukum normatif (normative legal research). Penelitian hukum yang meletakkan hukum sebagai sistem normatif. Pendekatan penelitian menggunakan pendekatan perundang-undangan (statute approach) dan pendekatan konseptual (conceptual approach). Hasil penelitian menunjukkan bahwa pemberlakuan Peraturan Mahkamah Agung Nomor 13 Tahun 2016 adalah memperjelas pedoman bagi Penuntut Umum dalam melakukan penuntutan kepada terdakwa korporasi dalam tindak pidana korupsi. Penerapan sanksi terhadap korporasi sebagai pelaku korupsi dilakukan sebagai upaya pengembalian kerugian Negara dan pemulihan perekonomian negara merupakan langkah tepat mengingat esensi pemidanaan pemberantasan tindak pidana korupsi yang bertujuan untuk memulihkan kerugian negara atau perekonomian negara.
\end{abstract}

Keywords: Korporasi; Korupsi; Tindak Pidana.

Citation: Muhammad Sofyan, Andi. 2019. "Corporate Prosecution in Criminal Acts of Corruption: Opportunity and Challenge". Mulawarman Law Review 4 (2), 105-15. https://doi.org/10.30872/mulrev.v4i2.67. 


\section{INTRODUCTION}

Corporation as law criminal especially in criminal acts of corruptiondoes not become controversy anymore. ${ }^{1}$ Corporation as law criminal subject (criminal law suspect) in Indonesia is officially adopted for the first time in 1951 on Emergency Law No. 14 Year 1951 on Hoarding of Goods. However that law practically did not regulate concerning corporation punisment as criminal suspect. That law did not decide in what cases (what are the requirements) that corporation could be reported to criminal court as act of criminal and it could be punished. ${ }^{2}$

Criminal Code itself follows act of criminal subject in form of "person" "look at Criminal Code of Article 59). Whereas corporate crime, could found in Law No. 3 Year 1989 concerning Telecommunication, Law No. 2 Year 1992 concerning Insurance, Law No. 10 Year 1995 concerning Custom, Law No. 11 Year 1995 concerning Excise, Law No.5 Year 1997 concerning Psychotropic, Law No. 23 Year 2009 concerning Narcotic, Law No. 31 Year 1999 as it was amandemended and added with Law No. 20 Year 2001 concerning the Eradication of Corporate Crime, Law No. 15 Year 2002 jo. Law No. 25 Year 2003 concerning Money laundering Criminal Acts.

J.E. Sahetapy states corporate crime is not the new object, but only its package, shape and form are new. Corporate crime exist was more than three thousands years age or in 24 a.d in Egypt. In the past on Greece, corporate crime was happened on Alcmaenoids who was given trust to build worship place with act of criminal subject (act of criminal suspect) in Indonesia officially was adopted for the first time in 1951 with Emergency Law No. 17 Year 1951 concerning Hoarding of Goods. However that law practice did not regulate concerning corporation punisment as criminal suspect.

On hystorical system, one of cases on the early of corporate justification acknowledgement in Indonesia criminal law, as followed: Supreme Court of Indonesia Republic decision on 1 March 1969 No. 136K/Kr/1966. In that cases, beside the Defendants were punished imprisonment, also they were punished with additional law which decides the industries of PT. Kosmo and PT. Sinar Sahar that were confiscated for 3 years and it was placed under Daperindra. ${ }^{3}$ From this case could be seen that an economic crime which was committed by coproration could be punished, towards the management or corporation itself.

Nowadays procuderal law on criminal acts of corruption with corporation was qualified by the emerged of Supreme Court Regulation of Indonesia Republic No. 13 Year 2016 on 21 December 2016 concerning Guidelines on Handling of Corporate Crime Cases, previously the Prosecutor General of Indonesia Republic emerged the Prosecutor General Regulation of Indonesia Republic No. PER-028 /A /JA /10 /2014 ON 1 October 2014 concerning the Guidelines on Handling of Crime Cases with Corporation Law Subject.

\footnotetext{
1 Suhariyanto, B. (2016). Restoratif justice dalam pemidanaan korporasi pelaku korupsi demi optimalisasi pengembalian kerugian negara.Jurnal Rechts Vinding: Media Pembinaan Hukum Nasional, 5(3), 421-438.

2 Sjahdeini, S.R. (2006), Pertanggungjawaban Pidana Korporasi, Jakarta: Grafiti Pers, hlm. 134.

3 Borahima, A. (2010). Kedudukan Yayasan di Indonesia (Eksistensi, Tujuan, dan Tanggung Jawab Yayasan), Jakarta : Kencana, hIm. 289.
} 
In handling cases of criminal acts of corruption with corporation law subject, punishment which is applied as followed as fine or money subtitutes punishment is not effective responsively to protect the victims interest of criminal acts of corruption in this case are country and people. It is proved by the impact of criminal acts of corruption which is committed by coroporation for example in construction procurement where it does not implemented or it does not have benefit which can be perceived by the country or people, people can uses structure or infrastructure to boost people's economy, but because of corporation acts which did corruption, then there is not any benefit received by the people, in fact country has allocated fund for development. ${ }^{4}$ Does after punishment of fine or money subtitutes is applied, then the original purpose of development can be achieved?, absolutely not, it needs long process until the next several years to achieve the final purpose of that development, even it can not be achieved, because of fine or money subtitutes can be not paid by the corporate defendants, or if it is paid, it will be state's income not tax that can be used directly for the job which was corrupted, but i must be processed by long bureaucracy budgeting.

\section{DISCUSSION}

\section{Handling of Cases Reality on Corporate Crime}

The corporation as an entity or legal subject whose existence contributes greatly in promoting economic growth and national development. However in reality, it is often for corporations to commit various criminal acts (corporate crime) that have a detrimental impact on the state and people. Moreover, corporation can be a place to hide wealth from crime which is untouchable by the law process in criminal liability. Based on that case, Supreme Court emerge Supreme Court Regulation No. 13 Year 2016 concerning Guidelines on Handling of Corporate Crime Cases.

Corporation mistake criteria in Supreme Court Regulation No. 13 Year 2016 on 21 December 2016 concerning Guidelines on Handling of Corporate Crime Case, Article 4 Paragraph (2) was, in punishing toward corporation, judge can determine the corporation's mistake, as followed as:

a. The potential benefit or advantage accruing to the corporation as a result of the offense and whether or not the offense was committed in the interests of the corporation

b. Whether or not the corporation acquiesced in the committing of the offense

c. Whether or not the corporation failed to take necessary action to prevent the occurrence of the offense, failed to take mitigation measures and/or failed to comply with the prevailing laws in order to prevent the occurrence of the offense.

\footnotetext{
${ }^{4}$ Maturbongs, P.P., Sofyan, A.M., Ruslan, A., and Muchtar, S. (2018). Responsive Legal Construction to Eradicate Corruption in the Procurement of Government Goods and Sevices, Journal of Law Pol'y \& Globalization 73, 109.
} 
Concerning punisment for corporation on Article 25 of Supreme Court Regulation No. 13 Year 2016 managed the judge punish corporate crime in form of main punishment and/or additional punishment, main punishment which referred is fine punishment whereas additional punishment is punised refer to law regulation. On Article 28 in the case of criminal fines meted out to the Corporation, the Corporation is granted a period of 1 (one) months since the ruling of the magnitude of the law remain to pay the fines. In case there is a compelling reason, such as the time period in paragraph (1) may be extended the longest one (1) month. It is if the convicted person does not pay the fine of the corporation referred to in subsection (1) and paragraph, the Corporation's property can be seized by prosecutors and auctioned off to pay a fine. On Article 32 manages a Corporation that is subject to additional criminal form of money substitutes, compensation and restitution, the guidelines for their implementation is carried out in accordance with the provisions of the legislation.

Now criminal acts or corruption cases by corporation which is decided (inkracht) in time interval after the enactment of Supreme Court Regulation No. 13 Year 2016, as follows as:

\section{PT. Puguk Sakti Permai (PT. PSP), Bengkulu}

Murman Effendi as Seluma Regent in 2010 emerged Regional Regulation No. 12 Year 2010 concerning Budget Fund for Infrastructure Development and Roads Improvement with Hotmix Construction via Multiyears Project for 5 years budget, with budget allocation of $\mathrm{Rp} 350.000 .000 .000,00$ which was from 5 years budget from Seluma Regional Revenue and Expenditure Budget (APBD) for 26 (twenty six) road projects. Based on government goods/services budgeting, PT. PSP on 8 February 2011 Joresmin Nuryadin bin Nurman Effendi (son of Murman Effendi) as an executive director, submitted tender of development project and roads improvement with hotmix construction, with tender Rp. 338.000.000.000,00. Based on that tender, PT. PSP on 10 March 2011 was selected as that project's auction winner. In fact, PT. PSP did not fulfill the requirements based on basic capacity to implement project with mount of Rp.36.000.000.000,00. Whereas infrastructure development project and roads improvement with hotmix construction reach $\mathrm{Rp} 350.000 .000 .000,00$. After PT. PSP was selected became the winner, then their project contract was enacted (project agreement) on 15 March 2011, with project coverage of road hotmix construction, with length of 79,844 KM consisted of 26 roads, with implementation due from 15 March 2011 until March 2015 with contract amount of Rp 338.000.000.000,00

Based on findings from construction expert and after the calculation was implemented by Board of Finance and Development Control (BPKP) on Bengkulu Province there were state's financial loss in the implementation on infrastructure development and roads improvement with hotmix construction which was implemented by PT. PSP with amount of Rp 4.100.000.000,00.

In the case development, Public Prosecutor Team from Chief Prosecutor's Office of Bengkulu and Seluma District Prosecutor's Office reviewed the case in Corruption Court on Chief Prosecutor's Office of Bengkulu, then on 16 February 2018, Council of Judges who checked and justified that case decided which stated PT. PSP was proven 
officially and found guilty by committing criminal acts of corruption. Punished fine toward PT. PSP with amount of Rp 200.000.000,00, in case of not paying the fine then it would be ubstitute by corporation's wealth deprivation or management personal with the same amount. In case of PT. PSP wealth sale or personel managements is not adequate, imprisonment for as the ubstitute punished toward personel management on Joresmin Nuryadin for 6 (six) months.

\section{PT. Putra Papua Perkasa (PT. PPP), West Papua}

Serious and commitment of Prosecutor's Office in handling of cases which involves corporation, does not only focus on capital and cities which have transportation access and complete and adequate infrastructure, but also reach to Papua region, as follows toward PT. PPP which is placed on Kaimana Regency, West Papua Province. PT. PPP as Defendants along with Suwita Sukendar ${ }^{5}$ as the Director of PT. PPP, Marthen Luther Rumades (Former Regional Secretary of West Papua Province) and Roy Letlora (Former Temporary Head Subtitute of PT. BNI (Persero) Tbk. Branch Office Manokwari in 2012 had against law by enrich self or another people or a corporation which possible caused loss to state's financial or state's economy.

Chronology the case of aquo, in 2008 there was inadequate fund for structure and infrastructure construction for Project Package of Jalan Ayawasi-Kebar in 2008 in West Papua Province in 2008 which is allocated on State Revenue and Expenditure Budget (APBN) in 2011 with amount of Rp 78.900.000.000,00 which was transferred to Regional General Treasury Account (RKUD) of West Papua Province on 28 December 2011. However, that fund did not allocate on Regional Revenue and Expenditure Budget (APBD) of West Papua Province in 2011 and 2012 as the payment toward invoice remains of Project Package of Jalan Ayawasi-Kebar in 2008. Afterward, Suwito Sukendar with Rico Sia (PT. PPP Commisioner) submitted letter to Head of Public Work and Spatial Planning of West Papua Province on 27 October 2011 concerning Invoice Payment Remains in 2008 and Contract Consideration Letter, which was an effort to raid state's money in corporation.

Based on the letter, Marthen L.R. emerged Letter of Fund Transferred and Account Balance Blocking on 13 January 2012, which then was processed by Roy Letlora with Fund Bookkeeping Transfer Rp 78.900.000.000,00 from Regional General Treasury Account in Bank BNI Branch Office Manokwari to account of PT. Putra Papua Perkasa. Fund usage $\mathrm{Rp} 78.900 .000 .000,00$ which was not allocated in Regional Spending and Budget against with Article 122 Paragraph (6) on Regulations of Minister of Home Affairs No. 13 Year 2006 concerning Guidelines for Management of Local Finances" which is Regulations of Minister of Home Affairs No. 59 Year 2007 which stated outcome could not be charged to spending allocation was not available or inadequate in Regional Revenue and Expenditure Budget (APBD) and it against provision on Article 132 Paragraph (3) which stated that treasury outcome which cause Regional Revenue and Expenditure Budget (APBD) could not be used before regional regulation draft

\footnotetext{
${ }^{5}$ Suwito Sukendar telah dipidana berdasarkan Putusan Pengendali Negeri Manokwari Nomor.18/ Pid.Sus-TPK/ 2016/ PN.MNK tanggal 6 Desember 2016. Sementara Roy Letlora masih dalam proses mengajukan upaya hukum Kasasi.
} 
concerning Regional Revenue and Expenditure Budget (APBD) was decided and placed on regional sheet.

Beside that, the fund bookkeeping transfer against with prevail provision because the official who asked bookkeeping on the availabe fund in Regional General Treasury Account (RKUD) does not have authority and not based on as managed in Government Regulation No. 58 Year 2005 concerning Regional Fund Management. ${ }^{6}$ Therefore , there were Suwito Sukendar letter as Director of PT.PPP concerning invoice remains payment in 2008 and contract consideration letter, along with Regional Secretary of West Papua Province on 13 January 2012 and 8 March 2012, fund with amount of Rp 78.900.000.000,00 as it was bookkept from Regional General Treasury (RKUD) to defendants of PT.PPP account that caused state's financial loss with amount of Rp 78.900.000.000,00 as the Report Audit Board of Indonesia Republic (BPK) based on Regional Spending of West Papua Province in 2011 and 2012 in Manokwarin on 18 January 2013.

In the progress of aqua case handling, Public Prosecutor Team from Chief Prosecutor's Office Papua and District Prosecutor Office of Manokwari, submitted criminal charge on 29 January 2018 toward defendants of PT. PPP with fine punisment with amount of Rp 50.000.000,00 and additional punishment in form of subtitute money with amount of Rp 78.900.000.000,00. Beside that, Public Prosecutor Team of District Prosecutor's Office from Manokwari also charged Council of Judges who checked and justified aquo case charged punishment in form of Revocation or Permission Closure Legal Business on PT. BPP for the longest time 1 year. Afterward on 14 February in 2018, Corruption Court on District Court of Manokwari charged decision which stated that defendants of PT. PPP was proved officially and convicted as guilty committed corporate corruption and charged punishment to defendants with fine punishment with amount of Rp 1.300.000.000,00, (one billions and three hundred thousands rupiah). Beside that, Council of Judges who checked and justified aqua case also charged additional punishment toward defendants to pay subtitute money with amount of Rp. 78.907.887.152,00, along with additional punishment in form of Revocation or Permission Closure Legal Business of PT. PPP for the longest time 1 year.

\section{PT. Kakas Karya, West Papua}

The other corporate crime handling of cases in land of Papua was also execute by the Executor's Office toward PT. Kakas Karya. In 2012, PT. Kakas Karya which was represented by Servie Rolly Prang did roads construction and bridge projects in South Sorong Regency. In the progress of its project, the defendant Cristian Mandagi as Site Manager of PT. Kakas Karya on 18 Desember 2012 created and signed several fictitious

\footnotetext{
${ }^{6}$ Pasal 61 ayat (1) PP Nomor 58 Tahun 2005 tentang Pengelolaan Keuangan Daerah menyatakan bahwa setiap pengeluaran harus didukung oleh bukti yang lengkap dan sah mengenai hak yang diperoleh oleh pihak yang menagih. Kemudian, dalam Pasal 65 ayat (1) dinyatakan bahwa pelaksanaan pengeluaran atas beban APBD dilakukan berdasarkan SPM (Surat Perintah Membayar) yang diterbitkan oleh pengguna anggaran/ kuasa pengguna anggaran dan pada Pasal 65 ayat (2) dinyatakan pembayaran sebagaimana dimaksud pada ayat 1 dilakukan dengan penerbitan SP2D (Surat Perintah Pencairan Dana) oleh kuasa BUD (Bendahara Umum Daerah).
} 
report concerning projects development of Boldon-Sesor roads construction in 2012 on South Sorong Regency with with finished realization statement $100 \%$.

Project's realization which $100 \%$ was not plausible because the project was not done or fictitious but it was directed to PT. Kakas Karya which was presented by Servie Rolly in order Christian Mandagi wanted to make and sign the project's administration document, such as Project Inspection Dossier reached 100\% then Regional General Treasury emerged Disbursement Order Warrant (SP2D) on 28 Desember 2012 with toal Rp 3.200.000.000,00 and Rp 171.000.000,00 which was paid to defendants of PT. Kakas Karya via Bank Papua Branch Teminabuan.

In reality, Jalan Boldon-Sesor project construction in 2012 on South Sorong Regency was fictitious or was not constructed because that project was just constructed in 2013 by CV. Tombolu Raya as contractor refer to contract and contracting agreement. Therefore, the impact of created and signed of fictitious documents as project completeness for road construction and brigdes in South Sorong Regency in 2012 was indicated to caused loss on state with amount of Rp 3.400.000.000,--. In progress of aquo handling of case, Council of Judge of Corruption Court on District Court of Manokwari on 8 February 2018 charged decision toward aquo case with fine punishment to defendants of PT. Kakas Karya with fine with amount of Rp 200.000.000,00 and charged ubstitute money with amount of Rp 2.700.000.000,00.

\section{PT. Proxima Convex, North Sumatra}

PT. Proxima Convex which is running in sector of affair management, small industries, meeting service, incentive trip, conference, and exhibition, was selected as Goods/Service Provider of training for Village Government Apparatus Capacity Improvement on North Sumatra Province in 2015 for Package/ Zona 1 from 8 November until 11 Desember 2015 placed in Pandan, Taruntung, Dolok Sanggul, Ajibata, and Sidikalang. After PT. Proxima Convex was chosen as another service provider for that event, the defendant Budhianto Suryanata as Director of PT. Proxima Convex along with Commitment Making Official (PPK) created contract which included there was paid clause that was done by termin system based on working realization and was at cost. ${ }^{7}$

In the event progress, PT. Proxima Convex as the event holder created written agreement and oral agreement with hotel management which was done and signed by Defendant as the Director PT. Proxima Convex. It had effect to Fullboard payment agreement value ${ }^{8}$ which was created by PT. Proxima Convex with hotel management was not as big as Fullboard price per piece which was put in contract and there was quite siginificant price interval.

Beside it, in Contract/RAB infocus allocation was the obligation of PT. Proxima Convex, but in fact they used infocus from hotel management. Then in invoice submission,

\footnotetext{
${ }^{7}$ At Cost adalah pembayaran biaya yang dikeluarkan sesuai dengan bukti pengeluaran yang sah.

8 Fullboard adalah paket kegiatan rapat /pertemuan yang diselenggarakan di luar kantor sehari penuh dan menginap.
} 
defendant created invoice/self facture with the same amount of fullboard price in contract to the Budget User without knowledge and agreement from hotel management, also submitting invoice for infocus rent payment, in fact defendant used hotel management infocus. The impact of defendant self act along with Edita DB Siburian (PPK) by enriched themselves was against the law because it against or contradicted with provision on the enacted law. Based on the loss result calculation which was done by Public Accountant Firm (KAP) Dr. Tarmizi Achmad, MBA. CPA., CA on 13 December 2016 was obtained state loss calculation with amount of Rp $599.105 .000,00$.

\section{PT. Fatimah Indah Utama (PT. FIU), West Sulawesi}

PT. FIU is a company which is one of its sector is in construction sector who run as holder on Nusantara Fish Fort (PPN) Palipi in Budget Year 2012 on Department of Maritime Affairs and Fisheries of West Sulawesi intentionally did not do the project refer to contract in Majene Regency. PT. FIU held held contract by involving people who were not part of themselves, but it was created as if it was part of PT. FIU. After contract signed, PT. FIU ignored their obligation to do the contract.

In contract implementation, not a single resource, the tools or manpower from PT. FIU was used or involved, PT. FIU did not control and supervise. Revetment construction which was part of PPN was created refer in the plan, that change did not include in contract addentdum and it was not based on analysis or technical justification, beside that several project items was not executed refer to contract or project volume was less. On 27 January 2013 was done the Provisional Hand Over/PHO) to Commitment Making Official (PPK) even infact that project was not reached $100 \%$. Because revetment's construction was not refer to plan and without analysis/technical justification, then before the maintenance finished, revetment construction was collapsed.

On the end of maintenance, PT. FIU did not do final hand over, but to avoid repairment toward damaged revetment construction, Field executor came to Head of Majene Regional Board of Disaster Management to be emerged the recommendation of revetment damage on PPN Palipi project was caused by natural disaster, recommendation was emereged without technical supervision although there was natural disaster but it does not have potential to cause damage on fish port building, because the natural disaster was still on preparedness level or classified as minor. Afterward based on that recommendation, the act of PT. FIU caused financial or economical loss to the country, which based on Audit Result from West Sulawesi Province Board of Finance and Development Control (BPKP) No.: SR- 68/ PW3/ 5/ 2016 on 5 April 2016 caused state's loss with amount of Rp. 1.366.796.147,10. In case decision, judge had same opinion to Public Prosecutor that PT. FIU was proved guilty committing criminal acts of in corporation then they were charged punishment in form of fine and additional subtitute money with the amount money that state had lost. 


\section{PT. Karya Putra Tunggal Jaya (PT. KPTJ), West Sulawesi}

PT. KPTJ which one of its business sector was construction acts as Executor for The Creation of Hydram Pump and its Equipment. The Providing and Repairment Activities of Farming Infrastructure in Budget Year 2009 on Majene Regency Department of Plantation and Farm Forestry of Majene Regence intentionally did not execute the project refer to contract. PT. KPTJ along with Ir. Akhsan as Commitment Making Official (PPK) agreed to replace Hydram Pump in order to obtain bigger interval payment. Beside that project item such as sediment catcher building and house of pump was constructed not refer to shop drawing. Waste pipe which is important part that cannot be separated with pump house in fact it was removed, it caused pump house was flooded, it became one of hydram pump could not function well but PT. KPTJ as the Project's Executor still wanted to accept $100 \%$ payment. The act of PT. KPTJ by enriced themselves, people, or a corporation, which PT. KPTJ received payement bigger than project which was finished than it could cause loss on state financial or economy, based on Audit Result Report of Board of Finance and Development Control from Representative of West Sulawesi Province No:SR-277/ PW32/ 5/ 2016 on 02 December 2016 caused state loss with amount of Rp. 976.193.070,78. In this case decision, judge had the same opinion with Public Prosecutor that PT. KPTJ was proved guilty and charged fine punishment along with additional punishment in form of subtitute money with the same amount of state had lost.

Before the enactment of Supreme Court Regulation No. 13 Year 2016, Prosecutor's Office did prosecution toward several corporations which are ... the prosecution was done by guidline with General Prosecutor of Indonesia Republic Regulation (Perja) No. PER-028/ A/ JA/ 10/ 2014 concerning Guidline for Handling of Criminal Case with Corporate Crime Subject. The enactment of Supreme Court Regulation No. 13 Year 2016 was to clarify Public Prosecutor to do prosecution toward corporation defendant in criminal acts of corruption, such as corporation investigation in court, calling letter format toward corporation, accusation format, and decision format.

\section{Conception of State Loss Return toward Corporation in Criminal Acts of Corruption}

Refer to essential criminal acts of corruption punishment which is put in explanation of UUPTPK consideration, which was the criminal acts of corruption eradication aims to restore state's financial or economy loss, then it was needed recent discussion concerning punishment form which was applied for corporation in criminal acts of corruption.

It has different position with individual law subject, corporation have organs outside of itself that are workers in that company who are not involved with decision that is run by management, but when corporation is punished then the workers will also feel the impact of punishment. ${ }^{9}$ Main punishment which is charged to corporation same with main punishment of imprisonment to someone, which gives suffering, if imprisonment to someone because their movement is restricted, then fine punishment for water

\footnotetext{
9 Hardiman, Y., Kotijah, S., \& Sina, L. (2019). Restorative Justice Terhadap Pelaku Tindak Pidana Ringan yang Telah diberi Sanksi Adat. Mulawarman Law Review, 4(1), 191-205.
} 
subsidy and corporation closure punishment also gives suffering to corporation body. Main punishment of fine which was charged to corporation based on Author was not inteded to restore state's economy

Additional punishment which was charged to corporation actually its essential to restore or return loss or to restore state's economy, was it effective to reach their purpose? Loss can be in form of public facility damage, bridge which should be used by people as economy connection but because of corruption it is damaged, medical device on hospital which should be for patients would be not fulfilled standard then it cannot be used because of corruption, school which is used by children to study becoming collapsed because of corruption.

State's loss was estimated by state's loss calculation expert which is requested by Public Prosecutor then it is submitted to the court to be put in accusation or then expert will be summoned to give statement in front council of judges. Loss which is submitted then put on Public Prosecutor Accusation Letter and it is decided by Council of Judges in order to make Defendant paying for the subtitute money as it is mentioned. That charged then will be executed by Public Prosecutor by put Subtitute Money to state's treasury which is earned by the Defendant. The money then will be in state's treasury, then how was the damage which is caused by acts of corruption from corporation?, is by putting money subtitute to state's treasury then the damage will be restored?, does the broken bridge can be rebuilt for economy connection?, or can medical device immediately used by doctor to treat the patients?, or can children immediately study peacefully in strong school building?, it is absolutely not.

On corruption case of PT. Fatimah Indah Utama as the previous discussion, criminal act of corruption was committed in 2012 which cause revetment of Palipi Nusantara Fish Port collapsed then fishing activity in that fish port could not function optimally as it was expected, even with end of this case in 2017 Defendant paid Subtitute Money, however until now fish port does not function optimally.

Punishment for subtitute money as implementation for state's loss restoration this time was done not only to restore state's loss but to give deterrent effect, but its weakness is in execution that it has obstacle, because defendant who is executed to subtitute money is still less of them who wants to voluntary transfer the money directly, then Prosecutor must confiscate the defendant's asset, but Prosecutor also experiences obstacle concerning difficulty to trace defendant's asset, therefore Prosecutor found the defendant's asset but only can cover from small amount of whole subtitute.

In fact, which is needed to think how to restore or control situation as if corporation does not commit corruption. As general case punishment, victim's interest should be listened, victim in criminal acts of corruption is the people. Regardless, construction which is executed by using people's money, and it is held for people's interest, for example harbor, irrigation, school, roads and bridges. When criminal act of corruption is exposed, punishment can solve the issue, how is with uncomplete construction, how is the damage which is inflicted or how is the uncomplete development, how can it immediately fulfill people's interest?, for exaample in case of PT. Fatimah Indah 
Utama, after this case is finished and the execution is finished, in fact there are remain issue and it is not finished, it is people's interest, especially for fishermen in Majene Regency who are not fulfilled, the should use fish port, it cannot be achieved because criminal act of corruption case. Therefore, the punishment renewal is needed to accomodate this issue.

Subtitute money which is transferred to state's treasury put as state's income not tax from Prosecutor's Office of Indonesia Republic, the fund blends and cannot be used directly for project construction which is damage because criminal act of corruption which is inflicted. Rebuilding must be reallocated and surely it has bureaucracy process and it requires long time.

In order to achieve repayment or financial loss or state's economy restoration, punishmed has very important role. What is arranged in criminal acts of law concerning additional punishment of subtitute money is one law makers effort for repayment or state's economy restoration.

\section{CONCLUSION}

The enactment of Supreme Court Regulation No. 13 Year 2016 clarifies the guideline for Public Prosecutor in order to execute prosecution to corpore crime defendant in criminal acts of corruption, such corporation investigation in court, calling letter format toward corporation, accusation format and decision format. Punishment implementation toward corporation as corruption defendant is done as an effort of state's loss repayment and state's economy restoration are the correct step considering the essential of criminal acts of corruption eradication which is oriented on state's loss repayment and state's economy restoration.

\section{BIBLIOGRAPHY}

Hardiman, Y., Kotijah, S., \& Sina, L. (2019). Restorative Justice Terhadap Pelaku Tindak Pidana Ringan yang Telah diberi Sanksi Adat. Mulawarman Law Review, 4(1), 191-205.

Maturbongs, P.P., Sofyan, A.M., Ruslan, A., and Muchtar, S. (2018). Responsive Legal Construction to Eradicate Corruption in the Procurement of Government Goods and Sevices, Journal of Law Pol'y \& Globalization 73, 109.

Suhariyanto, B. (2016). Restoratif justice dalam pemidanaan korporasi pelaku korupsi demi optimalisasi pengembalian kerugian negara. Jurnal Rechts Vinding: Media Pembinaan Hukum Nasional, 5(3), 421-438.

Borahima, A. (2010). Kedudukan Yayasan di Indonesia (Eksistensi, Tujuan, dan Tanggung Jawab Yayasan), Jakarta: Kencana.

Marzuki, P.M. (2005), Penelitian Hukum, Jakarta: Kencana Prenada Media Grup.

Muhammad, A. (2004), Hukum dan Penelitian Hukum, Bandung: Citra Aditya Bakti.

Sahetapy, J.E. (1994), Kejahatan Korporasi, Bandung: PT. Eresco.

Sjahdeini, S.R. (2006), Pertanggungjawaban Pidana Korporasi, Jakarta: Grafiti Pers. 